\title{
Policy, Preferences, and Patriarchy: The Division of Domestic Labor in East Germany, West Germany, and the United States
}

\begin{abstract}
Individual agency observed in the gendered division of labor is shaped by structural factors, but only recently has evidence emerged that the effect of women's resources varies systematically in its sociopolitical context. Here we use the 1994 International Social Survey Program to assess whether the relative effect of a proxy for women's and men's preferences-hallmark of individual choice-varies as well across three countries with divergent historical policy approaches regarding the private sphere. East German socialist policies required and supported women's employment; West German policy promulgated a male breadwinner model, and U.S. policy primarily remains silent on the private sphere. The division of domestic tasks and relative strength of individual preferences on shifting it vary by region. In the former East Germany the division of domestic labor is more egalitarian and the effect of preferences is small but equal for the genders. In West Germany the division is more traditional and preference effects are greater, but gender differences in these are insignificant. The U.S. division of domestic task falls between the two German regions, and the gender difference in preference effects is the greatest, with U.S. men's preferences predicting significantly more variance than do
\end{abstract}


U.S. women's. Consequently, allowing the market to dominate does not yield equal strength of preferences in the individual-level models used to predict the division of domestic tasks. This supports the dual-system feminist claims that capitalism can exacerbate nonmarket patriarchal hierarchies.

\section{Introduction}

Central to shaping gender relations within a society is the extent to which the labor market and the state reinforce the traditional gendered division of labor, where the man is the primary breadwinner while the woman specializes in the domestic sphere. Neoclassical economists (Becker 1981; Mincer and Polachek 1974) and some sociologists (Durkheim 1984 [1893]; Hakim 2000, 2003; Parsons 1942) contend that the gendered division of labor is an optimal allocation of family time, based on women's lower labor market returns and preferences for domestic tasks.

As to the market causes, the gender wage gap across countries remains real and persistent even after controlling for differences in education and experience (Blau, Ferber, and Winkler 2002; Blau and Kahn 1996; Gornick 1999). Despite women's lower returns, their labor force participation has steadily increased across industrialized countries, along with their relative economic equality in the household (Blau, Ferber, and Winkler 2002; Sorensen and McLanahan 1986). Across countries, the increase in men's share of unpaid domestic work and child care, however, has not been commensurate (Blossfeld and Drobnic 2001; Gershuny 2000).

Hakim (2000) claims that the gendered division of labor remains because modern society now provides women with more choices due to five historical changes: (1) the contraceptive revolution; (2) the equal opportunities revolution ensuring women have access to all positions, occupations, and careers; (3) expansion of white-collar occupations that are more attractive to women; (4) growth of the secondary job market providing part-time employment; and (5) the increasing importance of preferences in shaping lifestyle choices (Hakim 2003, 7). She argues that these changes have led to an increasing heterogeneity among women as to their preferences for market versus domestic work.

Because of this heterogeneity among women, women as a group do not support a single set of policies that affect the division of labor so that we do not observe any substantial change in its gendered nature (Hakim 2000). The two smallest groups, which she claims comprise about 20 percent each of a given population, consist of women who are the most traditional and most nontraditional. 
Women with traditional preferences support any policies reinforcing the male breadwinner model so that they might devote themselves to the domestic sphere, whereas women with the most nontraditional preferences support any policies reinforcing their greater competitiveness in the labor market. Hakim argues that the majority of women lies between the two, at times supporting male breadwinner policies and at times supporting dual-earner policies, depending on their current needs across the life course. Given their historical fulltime employment, men are more homogeneous in their preferences for full-time paid employment and policy support thereof (Hakim 2000).

There is a fundamental flaw in the logic of Hakim's argument. She ignores the extent to which the first four crucial changes are truly accessible to women and, in turn, constrain the fifth regarding their choice of lifestyle. Taking a structuralist rather than the individual agency approach Hakim uses, many argue that nonmarket hierarchies reinforce the gendered division of paid labor and are therefore the cause, not the outcome, of its existence. Early theorizing on this issue came from dual-systems feminists who claim that patriarchy exists, reflecting a hierarchical relation where women are subordinate to men in a gender-ordered division of labor in addition to the wage-ordered system (Eisenstein 1981; Hartmann 1979, 1981b; Walby 1990). Hartmann (1981b, 18) argues, "Capitalist development creates places for a hierarchy of workers, but ... [g]ender and racial hierarchies determine who fills the empty places," thereby structuring the observed occupational gender segregation and wage differentials (Hartmann 1979). It is advantageous for men to maintain this division, as they get greater control over economic resources and more time in leisure pursuits (Blau, Ferber, and Winkler 2002; Gershuny 2000).

Unlike the division of labor, however, it is difficult to find measures of patriarchy. But as it reflects the nonmarket presence of male dominance, the extent of its possible existence might be assessed by the extent to which nonmarket variables account for the division of domestic labor. To wit, while Becker (1981) and Hakim (2000, 2003) imply it is women's preferences for domestic tasks that result in their continued responsibility for them, it is possible that the household division of labor reflects men's preferences opposed to unpaid domestic work and that men's preferences dominate in a patriarchal society.

One way to ascertain whether it is individual preferences or an institutional and possibly patriarchal structure that is reflected in gender relations is to assess whether, controlling for relative economic resources, men's preferences are more important than 
women's in predicting the household time allocated to unpaid domestic tasks. If women's preferences are significant predictors of the reported division of domestic labor, this would support Hakim's contention that the gendered division of domestic labor reflects women's choice, although it does not eliminate the likelihood that the range of choices is socially constructed. If men's preferences predict more of the division of domestic labor than women's, this suggests there might be some element of patriarchal dominance beyond that derived from material relations.

Most U.S. studies find that men's gender ideology is more strongly associated with the division of domestic tasks than is women's, but in either case, attitudes account for very little variation in the division of labor (Shelton and John 1996). Fuwa (2004), using the United Nations's Gender Empowerment Measure, ${ }^{1}$ finds that the effect of women's gender ideology is stronger or weaker for women in more versus less egalitarian countries, respectively. Yet to date no one has assessed whether policy alters the relative strength of women's versus men's ideology in predicting the division of housework.

Here, data from the 1994 International Social Survey Program are used to compare to what extent women's and men's relative economic resources and gender ideology-used as a proxy for preferences-predict the division of unpaid labor in three regions providing contrasts in terms of policy impact on the private sphere: East and West Germany and the United States. The specific policy contrasts will be outlined in the next section, along with their hypothesized effects on the division of labor. The models and data are presented in the third section, with results presented in the fourth. The final section concludes.

\section{The State and the Gendered Division of Labor}

The family exists in a policy context, with policies varying by the extent to which there are gendered inequalities in employment and the value of paid work, as well as the nature and value of entitlements (O'Connor 1993; Orloff 1993). States vary in the degree to which they reinforce a woman's responsibility for unpaid care work in the home and her economic dependence on a male breadwinner (Lewis 1992) or mitigate her economic dependence, most frequently by enabling her to become integrated into the labor force (Hobson 1990).

The former East and West Germany enable us to compare the effect of radically different policies on people who share a common cultural past. At the end of World War II, five Länder separated to form East Germany, while the remaining formed West Germany. 
West Germany founded a new political system based on "natural law" (Naturrecht), stemming from a "pre-political" patriarchal order "ordained by God" (Moeller 1993). Social provisions favoring male breadwinners with nonworking wives were promulgated during the 1950s and 1960s under Konrad Adenauer (Gerhard 1992; Ostner 1992; Zimmerman 1993). Various tax provisions were introduced, such as income splitting, that proved particularly beneficial to highincome, single-earner families. Mothers were deemed the only satisfactory educators of their children (von Oertzen 1999), so in the 1960s public schools were set up with varying daily schedules and were closed over the lunch hour (Gornick, Meyers, and Ross 1997; Ostner 1993).

Fewer West German women than men graduated from the highest secondary school tracks; fewer still went on to university (Geschka 1989). The German educational system is highly stratified, with most students going on to some type of vocational education in lieu of university, yet there are clear gender differences in the type of occupational training selected (Geschka 1989). A 1966 federal report highlighted gender disparities in educational attainment and concluded that West German women's lack of educational pursuits were proving detrimental not to their employment prospects but to the education of their children (von Oertzen 1999).

In contrast, East Germany adopted a Stalinist constitution in 1949 that enforced women's obligation to work (Budde 1999; Moeller 1993; Trappe 2000). According to socialist doctrine, women's oppression is a function of capitalist social relations (Marx 1967). Therefore, the removal of women's economic dependence presumably eliminates gender subjugation. To support maternal employment, East Germany passed the 1950 Mother and Child Care and Women's Rights Acts, establishing a network of public child care centers, kindergartens, and facilities for free school meals, maternity leave, and days off to care for sick children (Ostner 1993; Zimmerman 1993). The state also mandated developing the skill credentials of women through education and vocational training (Budde 1999; Korn et al. 1984). A larger proportion of East German women attended professional colleges and university than in West Germany, although East German women still overwhelmingly selected just sixteen, traditionally female vocational tracks out of the hundreds available to them (Nickel 1992).

The East German pronatalist policies assumed women's responsibility for the domestic sphere, however, so maternity leaves, missed days caring for sick children, and the like were extra costs of female employees, with gender employment and earnings differences persisting (Einhorn 1993; Ferree 1992; Nickel 1992). The 1965 Family Law Code (Familiengesetzbuch) emphasized the equality of spouses 
and demanded a new male consciousness in child care and child-rearing, but no policies were implemented to support the rhetoric (Budde 1999; Zimmerman 1993).

The United States has similarities and differences with both German regions. The West German and U.S. welfare regimes are based on the principle of subsidiarity, where the family and nonstate institutions are primarily responsible for individual welfare (Esping-Andersen 1990; Ostner 1992). But West German policy explicitly relies on women's unpaid care work, whereas U.S. policy is essentially silent on the private sphere (Leibfried and Ostner 1991). As a liberal welfare regime, the United States encourages market participation but also relies on the market to supply any support for maternal employment (Gauthier 1996; Gornick, Meyers, and Ross 1997). Within the United States, religious beliefs are important as in West Germany, but a legal separation of church and state has limited religion's direct policy effects to primarily those concerning women's access to abortion, although this particular issue is so contested that it has become a regular platform for U.S. presidential candidates.

Since World War II, U.S. policy has primarily reflected the liberal tradition and addressed women's ability to compete in the labor market. ${ }^{2}$ U.S. women activists disagreed, however, as to whether policy should acknowledge gender difference, as in West Germany, or promote gender employment equality, as in East Germany (Costain 1992; Stetson 1995). A cornerstone piece of legislation addressed gender equality: employment, training, and education discrimination on the basis of gender became illegal under Title VII of the Civil Rights Act of 1964. During the 1970s, laws expanded enforcement of this legislation, promoting equal educational opportunities and job training. During the same period, policies acknowledging gender difference were also passed, including provisions for unpaid maternity leave rights, tax deductions for child care expenses for working parents, and women's right to control their reproduction (Costain 1992).

The influence of policy on the division of paid labor is evident in the relative 1990 married female labor force participation levels across the three regions. At the time of German reunification in 1990, over 90 percent of married women in the former East Germany were employed, almost 70 percent full-time, as compared with just 44 percent of married women in the west, only half of whom were employed full-time (Ostner 1993). The net wages of East German women working full-time were 76 percent of men's (Nickel 1992), as compared with 65 percent for West German women working fulltime (Frevert 1989; Gornick 1999). The United States passed some equal employment policies, as did East Germany (although in neither region was gender equality in employment achieved), but as in 
West Germany, the United States provided few social provisions to support maternal employment. By 1990, U.S. married women's employment was at 58 percent, 60 percent of whom were employed full-time, ${ }^{3}$ and the U.S. women's relative wage was 72 percent of men's (Blau, Ferber, and Winkler 2002), figures roughly midway between those for East and West German women.

Because these policy differences affect women's labor force participation levels and their relative economic resources, we would expect the aggregate division of domestic labor to be most egalitarian in East Germany, most traditional in West Germany, and somewhere in between in the United States. Any variation not accounted for by relative economic resources is a function of, taking the agentic line, individual preferences and/or, taking the structuralist line, patriarchal constraints. If these preferences are not socially constructed, then their relative importance should be similar across the genders and sociopolitical contexts.

If, however, a patriarchal structure results from capitalist relations as suggested by Marx, both East German men and women should hold the most nontraditional gender ideology, and neither should predict a greater variance in the division of domestic tasks. At the other extreme of capitalist development lies the United States, where one would expect relative economic resources to be significantly more important. At the same time, Eisenstein (1981) and Hartmann (1979, 1981b) claim that capitalism exacerbates patriarchy, so within this context, U.S. men's preferences should prove more significant than women's. In contrast, West German policy explicitly reinforced the male breadwinner model and women's responsibility for the domestic sphere, so ideology should be important when predicting the division of domestic labor. But given that separate roles were explicitly reinforced by the West German sociopolitical context, it is unclear whether men's preferences will prove more important than women's.

\section{Methods and Data}

The International Social Survey Program (ISSP) is a continuing annual program of cross-national research collaboration that utilizes preexisting social science projects and coordinates research goals in twenty-six countries. ${ }^{4}$ The 1994 module is the second on Family and Changing Gender Roles; the first was conducted in 1988. While both modules contain questions regarding gender roles and employment, only the 1994 module asks respondents about who does the domestic tasks. In addition, only the 1994 module contains East German respondents. There has been a more recent fielding of the survey in 
2002, but this would include East German couples who have lived a significant length of time under both German policy contexts. Therefore, the 1994 ISSP data are used to assess whether gender ideology, as a proxy for preferences, predicts the division of household labor beyond that predicted by relative economic resources.

The terms "gender ideology" and "preferences" are being used interchangeably. Hakim (1991) has argued that the types of attitudinal data used to derive measures of gender ideology are poor measures of preferences, in that people do not necessarily accept generalizations as applying to their own particular cases. Yet she acknowledges that there are at least weak associations between such attitudinal data and observed behavior. Further, others have found that gender ideology scales constructed from attitude questions identical to those within the data used here are significant predictors of the U.S. division of domestic labor (see Shelton and John 1996 for a review), so it seems plausible that they will prove significant predictors in other societies. In addition, while there might be some question of validity when using such data to derive a measure of preferences, the interest here is not in an absolute measure of preferences but rather the relative importance of men's versus women's. ${ }^{5}$

The ISSP interviews a single household respondent, sometimes the female and sometimes the male, so models will be run separately for the genders. As the division of labor is negotiated with a partner in the household, only married respondents less than sixty-five years of age will be selected. The age restriction is applied because persons over sixty-five are more likely to be retired, at the end of a lifetime of employment during which household patterns may have been established based on the historical division of labor rather than on current time allocations.

Only married persons are selected because while the ISSP asks for couples who are "married or living as married," the national survey centers confirmed that only married persons were included in this category. The rate of cohabitation has historically been much higher in the former East Germany as compared with either West Germany or the United States (Einhorn 1993; Ostner 1993), but in the last two countries it is most often a prelude to marriage, not a stable family state (Blossfeld 1995). Consequently, whether or not the couple cohabited with each other prior to the marriage is included as a control variable in the model.

A scale score of responsibility for domestic tasks in East and West German and U.S. married households will be regressed on individual measures of gender ideology and relative resource and other control variables with listwise deletion of missing data. Various imputations indicate the substantive results appear to be robust, so the more 
conservative approach of listwise deletion is selected so as not to reduce variance and inflate significance levels. Greenstein (1996) found a significant interaction effect between wives' and husbands' ideology and the division of household labor; types within a household cannot be ascertained with the ISSP data because only one adult is interviewed regarding their own attitudes. Instead, particular attention will be paid to the extent to which the independent female and male cross-sectional samples drawn for the ISSP appear complementary.

\section{Dependent Variable}

The scale measuring couples' relative responsibility for domestic tasks is derived from questions on who is normally responsible for (1) caring for the sick, (2) doing laundry, (3) doing the grocery shopping, (4) deciding what to have for dinner, and (5) doing small repairs (reverse coded). In a traditional division of domestic labor, the women would always do the first four tasks and the man would always do small repairs. ${ }^{6}$ Factor analysis (results not shown) reveals high loadings on a single factor for all but the fifth item, despite its reverse coding. Consequently, the domestic responsibility scale is created by summing responses across the four dominantly female tasks and dividing by four, resulting in a scale ranging from one, a traditional division of the unpaid labor where the woman is always responsible for the tasks, to five, a nontraditional division where the man is always responsible. Cronbach's (1951) alpha on the scale is 0.65 for West Germany, 0.55 for East Germany, and 0.70 for the United States, indicating fairly high internal consistency.

Mean responses on the scale by gender and region are shown in figure 1 . The difference in women's and men's reports is significant in West Germany and the United States but not East Germany. Where there is a significant difference, men report a more nontraditional sharing of the tasks than do the women, a result found in other studies using U.S. couple reports within a household (see Press and Townsley 1998). As anticipated, among women, East German women report the most nontraditional sharing of domestic responsibility, whereas West German women report the most traditional. U.S. men, however, unexpectedly report the most nontraditional sharing of domestic tasks of all the groups. The difference in gendered perceptions of who is responsible is also the greatest in the United States. Whether relative resources and gender attitudes explain these differences will be tested within the model.

\section{Independent Variables}

Gender Ideology Scale. Evidence indicates that where individuals hold a more traditional gender ideology, the division of domestic 


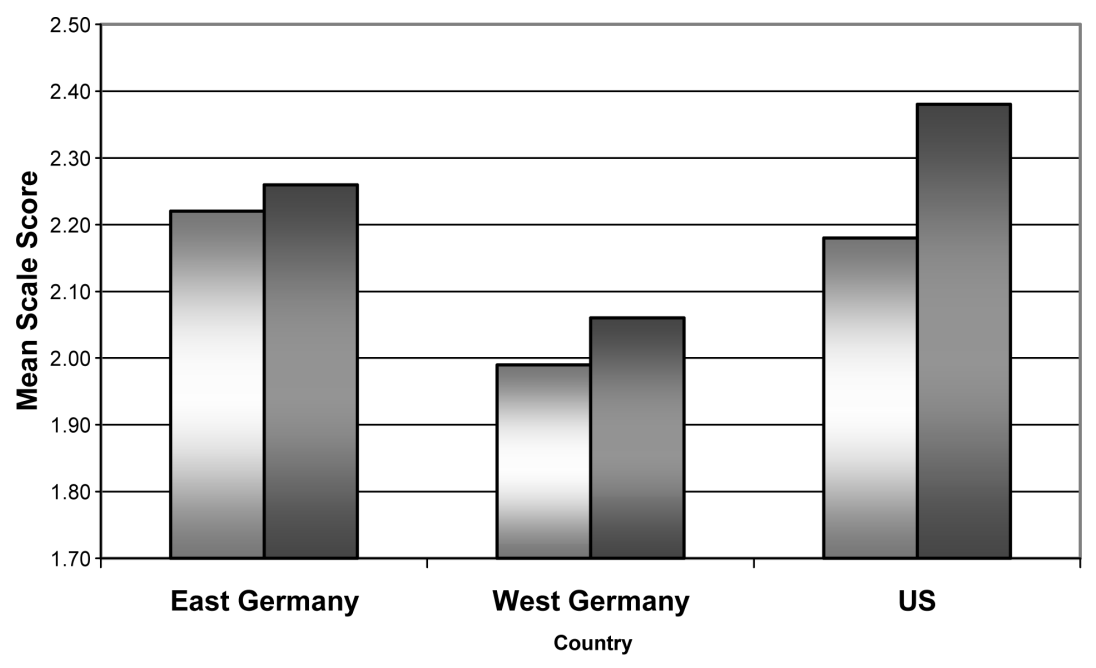

\section{$\square$ Women $\square$ Men}

Figure 1. Responsibility for Domestic Tasks Scale Reports by Gender East, West Germany and the United States.Married persons less than 65 years of age $1=$ Wife always responsible, 5 = Husband always responsible.

tasks is more traditional, and where individuals hold less traditional gender ideology, the domestic division is also less traditional (Blair and Lichter 1991; Presser 1994; Sanchez 1994). Fourteen questions in the ISSP assess the degree to which respondents support the traditional division of labor (see table 1). Six questions are recoded so that for all questions, a lower score indicates a more traditional gender ideology, while a higher score reflects a less traditional one. The fourteen measures are factor analyzed, with the factor loadings and Cronbach's alpha presented in table 2. Consistent across the countries are three general factors: Domestic, WorkingMom, and Economic. ${ }^{7}$ The Domestic factor consists of those variables emphasizing women's responsibility in the domestic sphere and the traditional division of labor: women want a home and child, housework satisfies as much as a paid job, and the husband should earn the money while the wife looks after the home. For West Germany, also loading high on this factor is that a reversal of traditional gender roles is not good. Cronbach's alpha indicates that the first three variables are internally consistent across the countries (Carmines and Zeller 1979).

The second factor, WorkingMom, consists of those four questions assessing attitudes on how well women can balance paid employment with family. The internal consistency on this scale approaches 
Table 1. Gender attitude questions on the 1994 International Social Survey Program

1. A working mother can establish just as warm and secure a relationship with her children as a mother who does not work. (R)

2. A preschool child is likely to suffer if his or her mother works.

3. All in all, family life suffers when the woman has a full-time job.

4. A job is all right, but what most women really want is a home and children.

5. Being a housewife is just as fulfilling as working for pay.

6. Most women have to work these days to support their families. (R)

7. Both the man and woman should contribute to the household income. (R)

8. A man's job is to earn money; a woman's job is to look after the home and family.

9. It is not good if the man stays at home and cares for the family and the woman goes out to work.

10. Women should stay at home full-time when there is a child under school age (three-point scale: home full-time, work part-time, work full-time).

11. One parent can bring up a child as well as two parents together. (R)

12. People who never have children lead empty lives.

13. A pregnant woman should be able to obtain a legal abortion for any reason whatsoever, if she chooses not to have the baby. (R)

14. Work is best for women's independence. (R)

Note: $(\mathrm{R})$ indicates reverse coding so that a higher score reflects more nontraditional attitudes.

0.70 across the countries. The internal consistency on the third factorbased scale, Economic, which assesses the extent to which women should contribute economically to the family and whether work provides women with independence, is lower at approximately 0.50 across the countries. ${ }^{8}$

To improve measure reliability, a single scale is created using the three consistent measures for Domestic and the four measures for WorkingMom. The scale is formed by summing responses on the seven variables and dividing by the number of variables so that each scale ranges from one, most traditional, to five, most nontraditional. These seven variables yield an alpha of 0.76 for West Germany, 0.77 for East Germany, and 0.77 for the United States, indicating very high internal consistency (Carmines and Zeller 1979).

\section{Control Variables}

Control variables include relative resources, log of total household income, age, children, whether the couple cohabited prior to the 


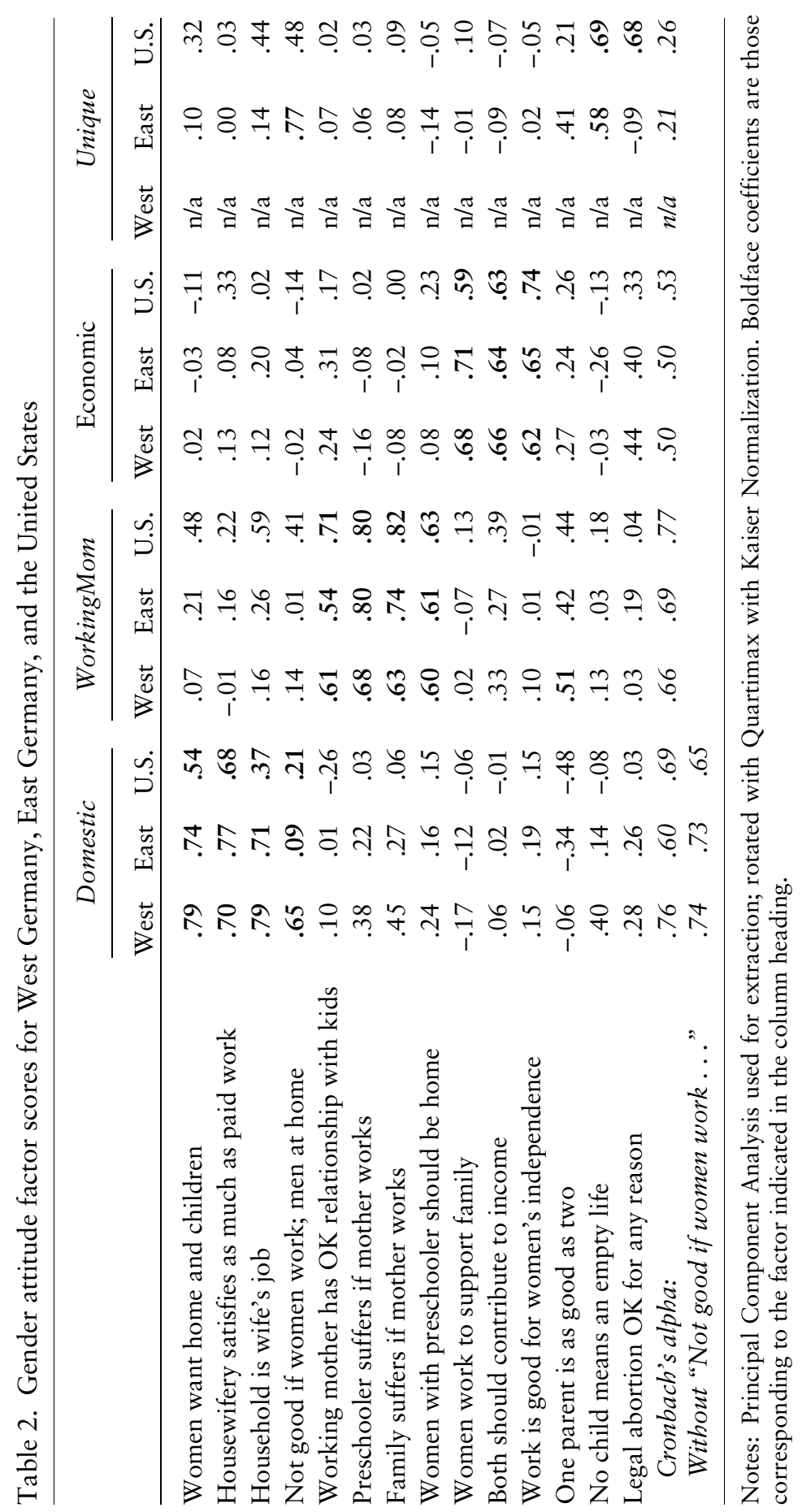


marriage, whether either partner is previously divorced, and religious service attendance. The first relative resource measure is an indicator variable for when wives are not employed. This is to differentiate effects between households with the traditional gendered division of paid labor and households with varying divisions of paid labor. The ISSP asks respondents about their own and their spouse's labor force status in terms of several possible categories. Persons reporting they are a homemaker, in education, unemployed, or out of the labor force are coded as not employed. Controlling for effects of the other variables, women who are not employed are expected to have greater responsibility for domestic tasks, as depicted by a negative coefficient on this variable.

Most studies have found that the smaller the gap between husbands' and wives' earnings, the more equal the division of household labor (Blair and Lichter 1991; Kamo 1991, 1994; Presser 1994; Shelton and John 1996). Earnings are measured here with a variable of the respondent's earnings as a percentage of total household income. A wage variable would have been preferred, but the ISSP data do not include hours of work for either German region with which to calculate hourly wages. On the other hand, the relative earnings measure does provide a proxy of relative family economic power. Women's greater relative earnings are expected to predict a more egalitarian division of responsibility for domestic tasks (a positive coefficient in the wives' models), whereas men's greater relative earnings are expected to predict a more traditional division of domestic responsibility (a negative coefficient in the husbands' models).

Educational attainment is often used as a measure of relative resources. Some U.S. evidence indicates that men's education level is positively associated with their domestic participation (Brines 1993; Presser 1994; South and Spitze 1994), while other studies find no association (Kamo 1991; McAllister 1990) or that the effect disappears once gender ideology is included (Kamo 1994). Women's greater educational attainment is associated with less time in domestic tasks (Blair and Lichter 1991; Brines 1993; South and Spitze 1994) and is normally interpreted as an education effect on ideology. Women's education could also, however, reflect an indirect effect of economic resources (controlled for in the model with the log of household income variable) and the use of purchased domestic services. In the model here, ideology is controlled for, and too few ISSP respondents report relying on a third person for domestic tasks. Education will be measured with a single indicator variable for when the respondent has postsecondary education, against a referent of secondary schooling or less. ${ }^{9}$ 
Children have been found to increase women's absolute and relative share of domestic tasks (Brines 1993; McAllister 1990; Presser 1994; Shelton and John 1996; South and Spitze 1994). This same effect is expected here, indicated if the child measure predicts a more traditional division of domestic responsibility (negative coefficient), with the effect possibly greater in West Germany where wives have been specifically charged with this responsibility. The presence of children is measured with an indicator variable when there are additional persons in the household, against a referent of a two-person household. ${ }^{10}$

Women's employment and domestic activity patterns have historically varied across the life course as they adapt to having children, with labor force participation rates higher early in adulthood, falling during childbearing years, and rising again once children reach school age. Consequently, age is modeled with three indicator variables: one where the respondent is less than thirty, one when s/he is thirty to thirty-nine, and one for when s/he is fifty to sixty-five. The referent is age forty to forty-nine, the prime labor force participation years for both men and women.

An indicator variable is also included for when the couple cohabited, against a referent of having not cohabited with the present spouse prior to marriage. Batalova and Cohen (2002) found that couples who cohabited prior to marriage have more egalitarian divisions of domestic tasks than couples marrying directly.

Two variables control for prior marriages, one indicating if the wife and one indicating if the husband was previously divorced, against a referent of not being previously divorced. While some evidence for the United States indicates that divorced men perform the greatest amount of domestic tasks relative to other men (South and Spitze 1994), Gupta (1999) finds that U.S. men's domestic share always declines when he is living with a woman.

Religious conceptions of family reinforce the traditional division of labor, but the role of religion varies in the three policy contexts. East German socialism discouraged religious attendance; West German policy incorporated religious conceptions of family; and there is a formal separation of church and state in the United States. Two indicator variables are used to capture the strength of religious conviction in each of the regions: one for persons attending religious services monthly or several times a year and one for persons attending more frequently, against a referent of persons never attending. More frequent religious service attendance is expected to predict a more traditional division of domestic responsibility. It is not speculated, however, how the different policy environments might alter these effects. 


\section{Results}

Descriptive statistics are reported in table 3. Comparing women's and men's responses suggests that the reporting is consistent in terms of household characteristics and relative earnings, regardless of the gender of the respondent. As would be expected in a male breadwinner state, West German wife-respondents report that almost half of them are out of the labor force, as compared with less than one-third of East German or U.S. wives. Among husband-respondents, the percentage whose wives are reportedly out of the labor force is slightly higher across the regions than reported by wife-respondents: 59 percent in West Germany, 38 percent in East Germany, and 32 percent in the United States.

Also as would be expected, a higher percentage of East German couples report cohabiting before marriage than in the other two regions, and U.S. couples are more likely to be in second marriages, with about one-fifth reporting either the wife or husband was previously divorced. About half of the U.S. respondents report attending religious services weekly or more frequently, whereas in the former West Germany, the majority attend religious services monthly or several times during the year. In the East German region, the majority of respondents report they do not attend religious services.

Regression results predicting the division of domestic responsibility are presented in table 4 . Two models are run for each gender within each country. The first model contains the relative resource and control variables. The second model adds the gender ideology scale score to ascertain whether this, as a proxy for preferences, significantly improves upon the relative resources model. The change in the $F$ statistic is significant for all groups except East German men and U.S. women, although it is only marginally significant for East German women. This supports that preferences, controlling for relative economic resources, are important predictors of the division of domestic labor, although the relative significance varies in its cultural context.

Only among U.S. men does having a wife out of the labor force predict that he will do significantly less of the domestic tasks, once controlling for the effects of the other variables. More consistent is the effect of a respondent's proportional earnings, except among East German women. For the other genders and regions, the more a man earns, the more traditional the division of domestic tasks, and the more the woman earns, the less traditional the division of domestic tasks. The size of this effect is roughly similar, with each percentage point increase in income shifting the division of labor 0.003 (East Germany) to 0.006 (United States) on the five-point scale. So 


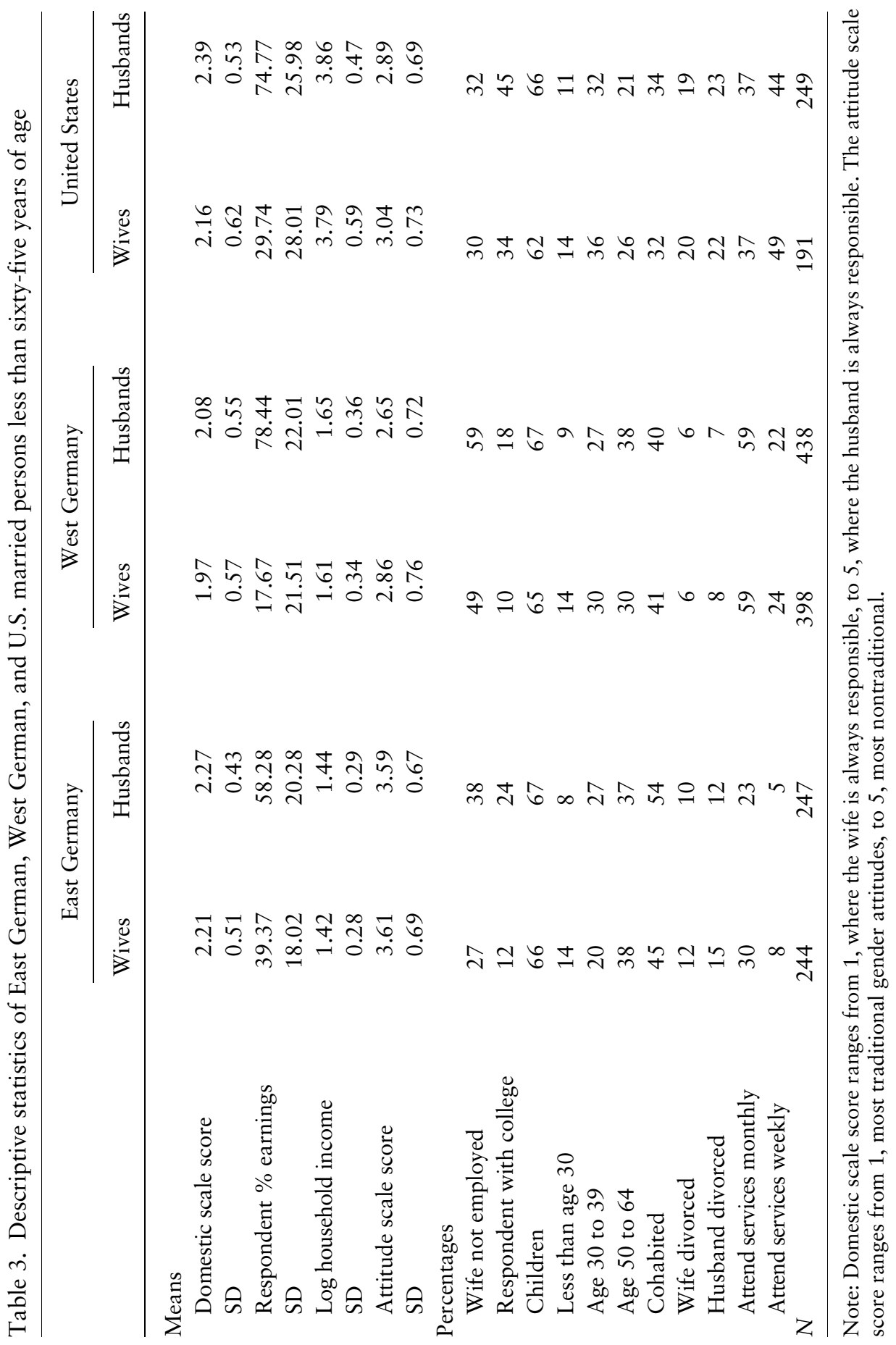




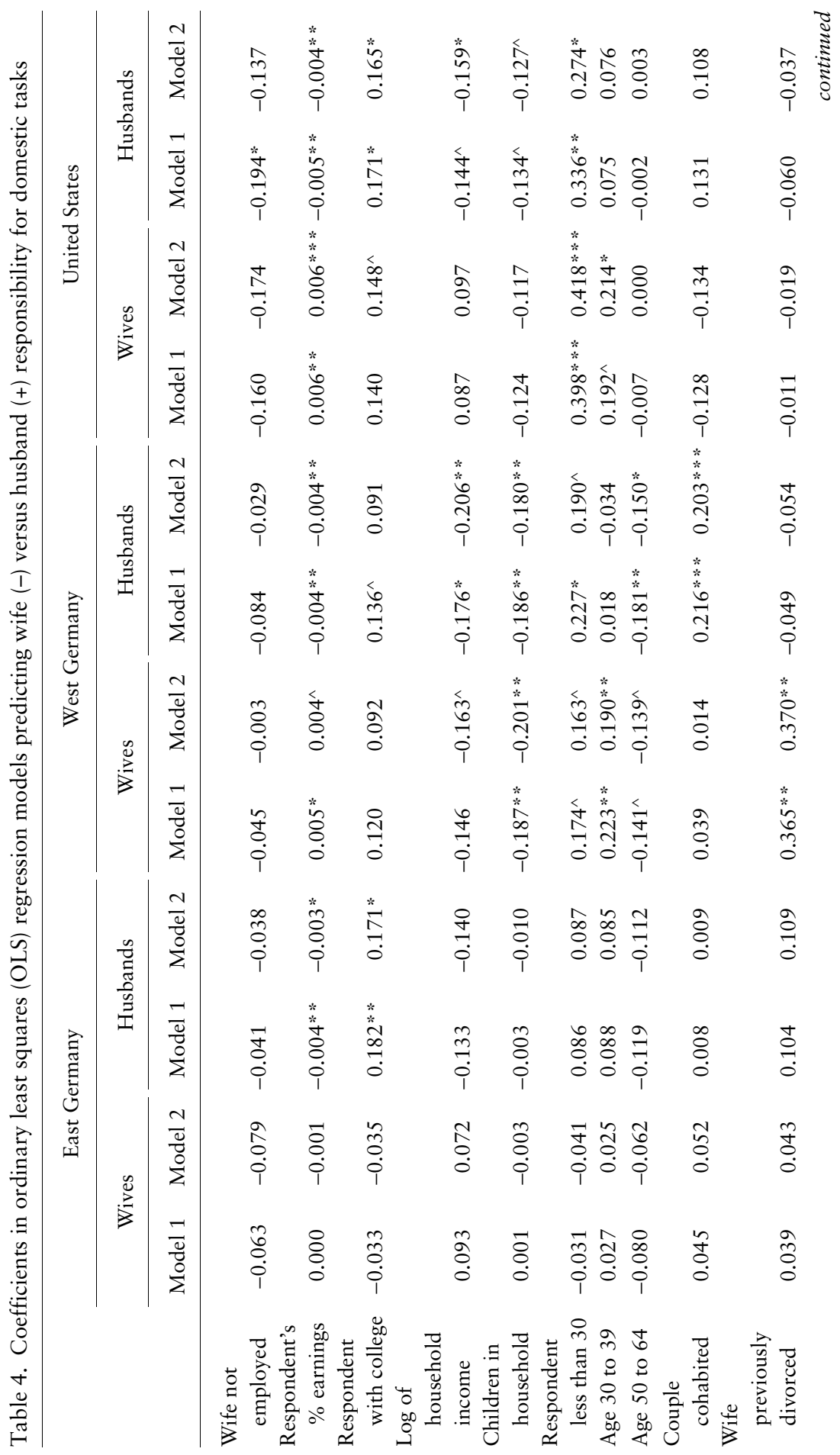




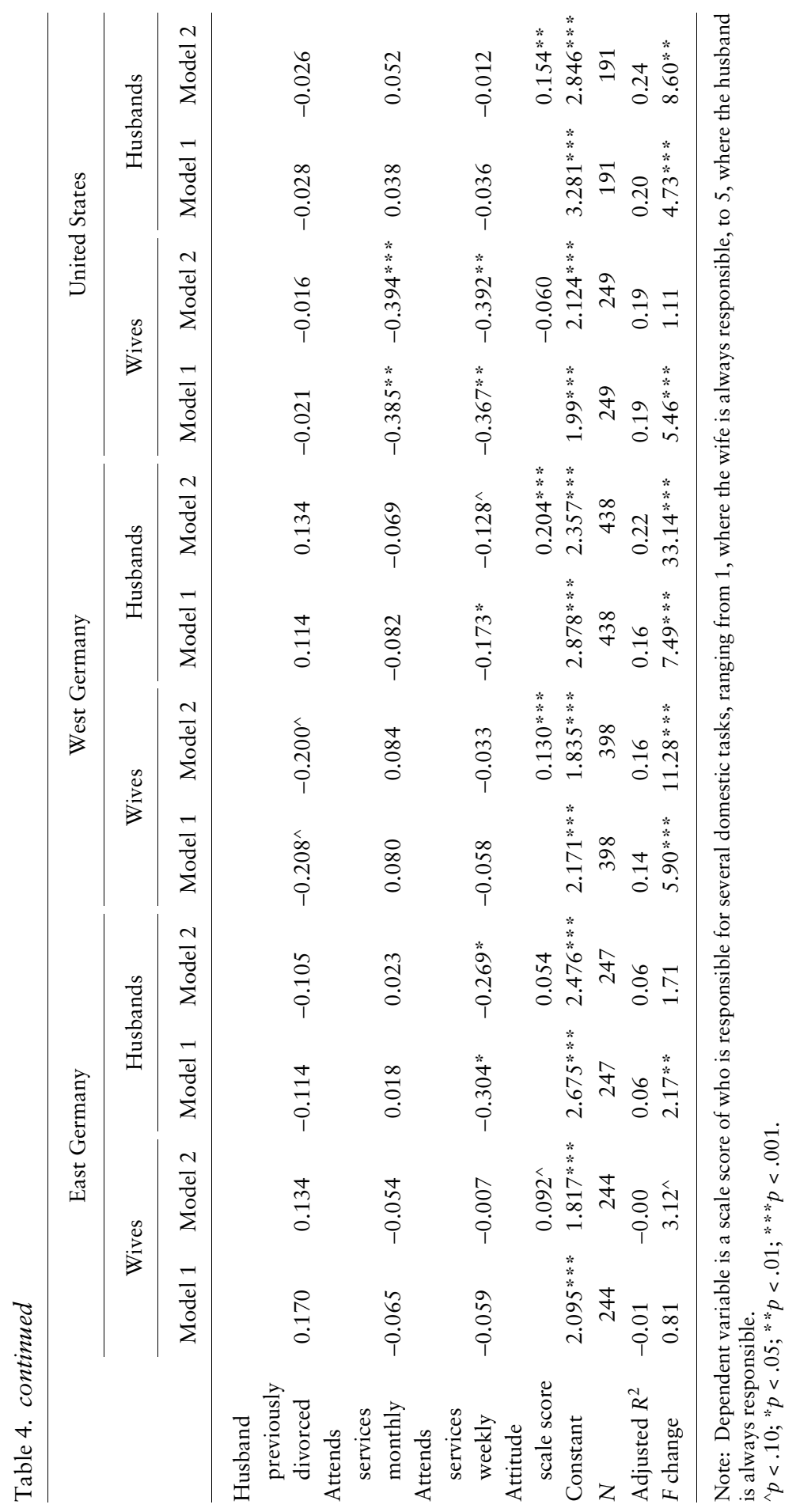


although earnings prove statistically significant, their substantive effects are quite modest, shifting the division of domestic responsibilities less than one scale point where the respondent is the sole breadwinner. In the case of female respondents, these results suggest that when she is the primary breadwinner of the couple, the division of domestic responsibilities is at best equal. These results are consistent with other findings that couples "do" gender in domestic tasks to reinforce masculine and feminine identities when the traditional economic roles are reversed (Fenstermaker Berk 1985; Brines 1994; Hochschild 1989; West and Zimmerman 1987).

Controlling for relative earnings, West German women and men and U.S. men report that households with greater income have a more traditional division of domestic tasks. The magnitude of the income effect is approximately equal to-and in the opposite direction of-education effects. As found in other empirical studies, men with college education report a more egalitarian division of domestic responsibility. A similar effect is found for U.S. women respondents after controlling for gender ideology, although this effect is just marginally significant. For East German and U.S. men, the significant education effect persists after controlling for gender ideology, whereas it attenuates for West German men.

The presence of children in the household predicts a more traditional division of domestic tasks for both West German genders and for U.S. men, although in the latter case, the effect is marginally statistically significant. Age effects are also apparent in West Germany and the United States. Controlling for the presence of children, younger U.S. and German persons report a more nontraditional division of domestic tasks than the referent group of persons in their forties. For both West German genders only, being the oldest age group, having grown up during the height of the pater familias rhetoric of the Adenauer years, predicts a more traditional division.

Cohabitation and previous divorce effects are only significant among West Germans. West German men who cohabited prior to marriage report a significantly more nontraditional division of domestic tasks, but West German women do not appear to concur. When a West German woman has been previously divorced, however, she reports a more nontraditional division of domestic tasks, whereas when a West German woman reports her husband has been divorced, the division is more traditional. West German men report no similar divorce effects for either themselves or their wives.

Attendance at religious services has significant effects in all three regions but not across the genders. Both East and West German men attending religious services weekly or more frequently are predicted to have a more traditional division of domestic tasks, but attendance 
is insignificant for these regions' wife-respondents. In contrast, U.S. women attending religious services at any frequency are predicted to have a more traditional division of domestic tasks, but U.S. husbandrespondents attending services report no similar effect. All of these religion effects are controlling for attitudes, so some of the influence of religion on reinforcing normative male and female roles appears to be direct.

As noted at the beginning of this section, inclusion of the preference measure significantly improves the model except among U.S. women. The smallest difference between women's and men's coefficients on the preference measure is found in East Germany. ${ }^{11}$ These results suggest that socialist policies can reduce at least some of the gendered differences in the allocation of time to domestic labor, although the aggregate data suggests that East German women still retain primary responsibility. At the other end of the capitalist continuum, preferences are insignificant in predicting the division of domestic labor among U.S. women but are highly significant among U.S. men. The difference between the two U.S. genders is also the only preference coefficient difference that reaches statistical significance. Finally, preferences explain a significant amount of the variation in the division of domestic labor in West Germany for both men and women, but the difference between the genders is not statistically significant.

\section{Summary and Conclusions}

International Social Survey Program data have been used to compare the effects of measures of individual agency—relative resources and a proxy for preferences-on the gendered division of domestic labor across, and whether women's or men's preferences dominate within, differing sociopolitical contexts. The country cases of East and West Germany and the United States were selected as varying the degree of policy reliance on women's unpaid work in the private sphere.

Results reveal that while relative resources alter the division of domestic labor across the three regions, women are still apt to spend more time in domestic tasks than men. Preferences prove significant for all but East German men and U.S. women, but the size of these effects is modest. That preferences do not fully account for the remaining variance in the division of domestic labor once controlling for relative resources could support Hakim's contention that attitudes are at best weak measures of preferences. Alternatively, these results could reflect that the gendered division of domestic labor is structurally determined and cannot be explained 
away by individual factors. Differentiating between these two possible explanations requires that preference, not just attitude, measures are incorporated in future cross-national social survey programs.

As would have been predicted by Marx, the division of domestic labor is slightly more egalitarian among East German couples, and East German women's preferences are as important as men's in predicting movements from this average. But the socialist structure by no means eliminated gender differences in the home. In contrast, the difference between U.S. women's and men's preference coefficients is the only regional gender difference to reach statistical significance, with U.S. men's preferences being more important determinants of the division of domestic labor than women's. This suggests some support for the dual-feminist claim that a purely capitalist structure may exacerbate patriarchy.

In West Germany preferences explain a significant amount of the variation in the division of domestic labor for both men and women, but the difference between the genders is not statistically significant. Thus, an explicitly patriarchal structure does not necessarily increase the relative gender strength of preferences in determining the division of domestic labor. This is not to say that the patriarchy reinforced in West German policy is less effective at institutionalizing it, but its effects are not reflected in gender preference differences. West German women's reinforced domestic responsibility is evident in significant effects found for having children.

One benefit of explicit policy, however, is that it can explicitly be challenged and changed. Evidence of this may be manifesting in the strong secular effects toward more egalitarian domestic labor divisions found for the younger West German persons as compared with those oldest respondents growing up during the height of the male breadwinner policy rhetoric. Whether explicitly nonpatriarchal policy in a capitalist society would have the desired effect in shifting the division of domestic labor, or merely have patriarchal effects subsumed within individual preferences, is unknown.

Clearly, however, the market alone does not ensure egalitarian gender relations and may in fact exacerbate the nonmarket hierarchies. Further comparative research is needed to disentangle these interwoven effects and where in our models they manifest.

\section{NOTES}

Lynn Prince Cooke is a postdoctoral research fellow in the School of Social and Behavioural Science at University of Queensland. She recently completed her doctorate at Oxford University and researches the effect of policy on gender equity and equity effects on family outcomes. Her work 
has appeared in European Sociological Review and Journal of Marriage and Family, and her article on "doing" gender in context is forthcoming in American Journal of Sociology. She is currently working on a book comparing policy effects on gender power and family outcomes in seven countries.

1. The Gender Empowerment Measure consists of the percentage of parliamentary seats held by women, the percentage of women in administrative or managerial, as well as professional or technical positions, and women's share of earnings income.

2. Feminist or reformer concerns for women as mothers also played a key role in U.S. policy, particularly at the end of the nineteenth and beginning of the twentieth centuries. Orloff (1996) provides a review of the scholarship documenting this era. The discourse changed, however, with attempts to eliminate marriage bars implemented during the Great Depression (Hobson 1993).

3. Calculated from the 1995 Statistical Abstract of the United States, tables 637 and 677.

4. More information on the ISSP, including codebooks, is available at http://www.issp.org (accessed 26 January 2006).

5. Comparing the relative importance of the measures to the genders within each region also reduces the concern regarding response bias due to social desirability that might vary across contexts.

6. One response category was "tasks done by third person," although it was unclear if this was hired assistance or other family members. Further, few respondents answered in this way and whether third persons were used for each of the tasks varied, so this category was recoded as missing. For the most part, third persons were most likely to be used to conduct the small repairs.

7. Braun, Scott, and Alwin (1994) also derived three similar core factors for East and West Germans using the 1988 ISSP, so these factors appear to be stable across time. Using different data, the 1991 German General Social Survey, they found only two factors, but the questions were phrased and scaled differently than ISSP questions (Braun, Scott, and Alwin 1994).

8. While the Domestic, WorkingMom, and Economic factors are common to all three countries and explain about half the variance in responses to the fourteen questions, both East German and U.S. responses each yield a marginally significant, but not the same, fourth factor, displayed in the final columns of table 2. For East Germany, the fourth factor consists of the questions regarding gender role reversal and whether having no children means an empty life, although the internal consistency is very low. For the United States, questions on legal abortion and whether having no children means an empty life form a factor. While these fourth factors illustrate the unique cultural aspects of gender attitudes in East Germany and the United States, they are not comparable across the countries and have low internal consistency and are excluded from the analyses.

9. Very few persons in the German regions report not completing secondary schooling, so a referent of less than secondary schooling could not be used against which to compare effects of secondary schooling. The percentage of U.S. persons without secondary schooling is more substantial, at around 10 percent. 
10. This is the best proxy for children available with the ISSP data across the countries. Another variable asked for life course status in terms of how many adults and children lived in the household, but missing data on this variable were more extensive than on the variable used.

11. The relative size of effects is calculated as the difference in the unstandardized coefficients divided by the standard error of this difference (the square root of the sum of the squared standard errors of each coefficient). This difference can be statistically significant even if any individual coefficient has not been shown to be statistically different from zero in predicting the dependent variable.

\section{REFERENCES}

Batalova, Jeanne A., and Philip N. Cohen. 2002. "Premarital Cohabitation and Housework: Couples in Cross-National Perspective." Journal of Marriage and Family 64: 743-55.

Becker, Gary S. 1981. A Treatise on the Family. Cambridge, Mass.: Harvard University Press.

Blair, Sampson L., and Daniel T. Lichter. 1991. "Measuring the Division of Household Labor: Gender Segregation of Housework among American Couples." Journal of Family Issues 12: 91-113.

Blau, Francine D., Marianne A. Ferber, and Anne E. Winkler. 2002. The Economics of Women, Men, and Work. 4th ed. Englewood Cliffs, N.J.: Prentice-Hall.

Blau, Francine D., and Lawrence M. Kahn. 1996. "Wage Structure and Gender Earnings Differentials: An International Comparison." Economica 63 (suppl.): S29-S62.

Blossfeld, Hans-Peter. 1995. "Changes in the Process of Family Formation and Women's Growing Economic Independence: A Comparison of Nine Countries." In The New Role of Women: Family Formation in Modern Societies, ed. Hans-Peter Blossfeld, 3-32. Boulder, Colo.: Westview Press.

Blossfeld, Hans-Peter, and Sonja Drobnic. 2001. A Cross-National Comparative Approach to Couples' Careers. Oxford, U.K.: Oxford University Press.

Braun, Michael, Jacqueline Scott, and Duane F. Alwin. 1994. "Economic Necessity of Self-Actualization? Attitudes Toward Women's LabourForce Participation in East and West Germany." European Sociological Review 10 (1): 29-47.

Brines, Julie. 1993. "The Exchange Value of Housework." Rationality and Society 5: 302-40.

- 1994. "Economic Dependency, Gender, and the Division of Labor at Home." American Journal of Sociology 100: 652-88.

Budde, Gunilla-Friederike. 1999. "Women's Policies in the GDR in the 1960s/70s: Between State Control and Societal Reaction.” In State Policy and Gender System in the Two German States and Sweden, 1945-1989, ed. Rolf Torstendahl, 199-217. Lund, Sweden: Bloms i Lund Tryckeri AB.

Carmines, Edward G., and Richard A. Zeller. 1979. Reliability and Validity Assessment. Beverly Hills, Calif.: Sage. 
Costain, Anne N. 1992. Inviting Women's Rebellion: A Political Process Interpretation of the Women's Movement. Baltimore, Md.: Johns Hopkins University Press.

Cronbach, Lee J. 1951. "Coefficient Alpha and the Internal Structure of Tests." Psychometrica 16: 297-334.

Durkheim, Emile. 1984 [1893]. The Division of Labor in Society. New York: Free Press.

Einhorn, Barbara 1993. Cinderella Goes to Market: Citizenship, Gender, and Women's Movements in East Central Europe. London: Verso.

Eisenstein, Zillah R. 1981. The Radical Future of Liberal Feminism. New York: Longman.

Esping-Andersen, Gosta. 1990. The Three Worlds of Welfare Capitalism. Princeton, N.J.: Princeton University Press.

Fenstermaker Berk, Sarah. 1985. The Gender Factory: The Apportionment of Work in American Households. New York: Plenum Press.

Ferree, Myra Marx. 1992. "Institutionalizing Gender Equality: Feminist Politics and Equality Offices." German Politics and Society 24-25 (Winter 1991-92): 53-65.

Frevert, Ute. 1989. Women in German History: From Bourgeois Emancipation to Sexual Liberation. Oxford, U.K.: Berg.

Fuwa, Makiko. 2004. "Macro-Level Gender Inequality and the Division of Household Labor in 22 Countries." American Sociological Review 69: 751-67.

Gauthier, Anne Hélène. 1996. The State and the Family: A Comparative Analysis of Family Policies in Industrialized Countries. Oxford, U.K.: Clarendon Press.

Gerhard, Ute. 1992. "German Women and the Social Costs of Unification." German Politics and Society 24-25 (Winter 1991-92): 16-33.

Gershuny, Jonathan. 2000. Changing Times: Work and Leisure in Postindustrial Society. Oxford, U.K.: Oxford University Press.

Geschka, Otti. 1989. "Participation and Disadvantage: Women in the Educational System." In The Federal Republic of Germany, ed. Eva Kolinksy, 189-98. Oxford, U.K.: Berg.

Gornick, Janet C. 1999. "Gender Equality in the Labour Market: Women's Employment and Earnings." In Gender and Welfare State Regimes, ed. Diane Sainsbury, 210-42. Oxford, U.K.: Oxford University Press.

Gornick, Janet C., Marcia K. Meyers, and Katherin E. Ross. 1997. "Supporting the Employment of Mothers: Policy Variation across Fourteen Welfare States." Journal of European Social Policy 7: 45-70.

Greenstein, Theodore N. 1996. "Husbands' Participation in Domestic Labor: Interactive Effects on Wives' and Husbands' Gender Ideologies.” Journal of Marriage and Family 58: 585-95.

Gupta, Sanjiv. 1999. “The Effects of Transitions in Marital Status on Men's Performance of Housework." Journal of Marriage and Family 61 (3): 700-711.

Hakim, Catherine. 1991. "Grateful Slaves and Self-Made Women: Fact and Fantasy in Women's Work Orientations.” European Sociological Review 7: 101-21. 
2000. Work-Lifestyle Choices in the 21st Century: Preference Theory. Oxford, U.K.: Oxford University Press.

- 2003. Models of the Family in Modern Societies: Ideals and Realities. London: Ashgate.

Hartmann, Heidi. 1979. "Capitalism, Patriarchy, and Job Segregation by Sex.” In Capitalist Patriarchy, ed. Z. R. Eisenstein, 206-247. New York: Monthly Review Press.

- 1981a. "The Family as the Locus of Gender, Class, and Political Struggle: The Example of Housework.” Signs 6: 366-94.

-. 1981b. "The Unhappy Marriage of Marxism and Feminism: Towards a More Progressive Union." In Women and Revolution: A Discussion of the Unhappy Marriage of Marxism and Feminism, ed. Lydia Sargent, 1-41. London: Pluto Press.

Hobson, Barbara. 1990. "No Exit, No Voice: Women's Economic Dependence and the Welfare State." Acta Sociologica 33: 235-50.

- 1993. "Feminist Strategies and Gendered Discourses in Welfare States: Married Women's Right to Work in the United States and Sweden." In Mothers of a New World: Maternalist Politics and the Origins of Welfare States, ed. Seth Koven and Sonya Michel, 396-429. New York: Routledge.

Hochschild, Arlie, with Anne Machung. 1989. The Second Shift: Working Parents and the Revolution at Home. London: Piatkus.

Kamo, Yoshinori. 1991. "A Nonlinear Effect of the Number of Children on the Division of Household Labor." Sociological Perspective 34: 205-18.

-1994. "Division of Household Work in the United States and Japan.” Journal of Family Issues 15: 348-78.

Korn, Klaus, Günter Feierabend, G. Hersing, and H.-D. Reuschel. 1984. Education, Employment, and Development in the German Democratic Republic. Paris: UNESCO International Institute for Educational Planning.

Leibfried, Stephan, and Ilona Ostner. 1991. "The Particularism of West German Welfare Capitalism: The Case of Women's Social Security.” In The Sociology of Social Security, ed. Michael Adler, Colin Bell, Jochen Clasen, and Adrian Sinfield, 164-86. Edinburgh, U.K.: Edinburgh University Press.

Lewis, Jane. 1992. "Gender and the Development of Welfare Regimes." Journal of European Social Policy 3: 159-73.

Marx, Karl. 1967. The Manifesto of the Communist Party. Middlesex, Eng.: Penguin.

McAllister, Ian. 1990. "Gender and the Division of Labor: Employment and Earnings Variation in Australia." Work and Occupations 17: 79-99.

Mincer, Jacob, and Solomon Polachek. 1974. "Family Investments in Human Capital: Earnings of Women.” Journal of Political Economy 82 (Part II): S76-S108.

Moeller, Robert G. 1993. Protecting Motherhood: Women and the Family in the Politics of Postwar West Germany. Berkeley: University of California Press. 
Nickel, Hildegard Maria. 1992. "Women in the German Democratic Republic and in the New Federal States: Looking Backwards and Forwards." German Politics and Society 24-25 (Winter 1991-92): 34-52.

O’Connor, Julia. 1993. "Gender, Class, and Citizenship in the Comparative Analysis of Welfare State Regimes: Theoretical and Methodological Issues." British Journal of Sociology 44: 501-18.

Orloff, Ann Shola. 1993. "Gender and the Social Rights of Citizenship: The Comparative Analysis of Gender Relations and Welfare States." American Sociological Review 58: 303-28.

-1996. "Gender in the Welfare State." Annual Review of Sociology 22: 51-78.

Ostner, Ilona. 1992. "Ideas, Institutions, Traditions: The Experience of West German Women, 1945-1990.” German Politics and Society 24-25 (Winter 1991-92): 87-99.

- 1993. "Slow Motion: Women, Work, and the Family in Germany." In Women and Social Policies in Europe: Work, Family and the State, ed. Jane Lewis, 92-115. Aldershot, U.K.: Edward Elgar.

Parsons, Talcott. 1942. "Age and Sex in the Social Structure of the United States." American Sociological Review 7: 604-16.

Press, Julie E., and Eleanor Townsley. 1998. "Wives' and Husbands' Housework Reporting: Gender, Class, and Social Desirability." Gender and Society 12 (2): 188-218.

Presser, Harriett B. 1994. "Employment Schedules among Dual-Earner Spouses and the Division of Household Labor by Gender." American Sociological Review 59: 348-64.

Sanchez, Laura A. 1994. "Gender, Labor Allocations, and the Psychology of Entitlement in the Home." Social Forces 73: 533-53.

Shelton, Beth A., and Daphne John. 1996. "The Division of Household Labor.” Annual Review of Sociology 22: 299-322.

Sorensen, Annemette, and Sara McLanahan. 1986. "Women's Married Economic Dependency, 1940-1980.” American Journal of Sociology 93: 659-87.

South, Scott J., and Glenna Spitze. 1994. "Housework in Marital and Nonmarital Households." American Sociological Review 59: 327-47.

Stetson, Dorothy McBride. 1995. “The Oldest Women's Policy Agency: The Women's Bureau of the United States." In Comparative State Feminism, ed. Dorothy McBride Stetson and Amy Mazur, 254-71. Thousand Oaks, Calif.: Sage.

Trappe, Heike. 2000. "Work and Family in Women's Lives in the German Democratic Republic." In Work and Family: Research Informing Policy, ed. Toby L. Parcel and Daniel B. Cornfield, 5-29. Thousand Oaks, Calif.: Sage.

von Oertzen, Christine. 1999. "Women, Work, and the State: Lobbying for Part-Time Work and 'Practical Equality' in the West German Civil Service, 1958-1969." In State Policy and Gender System in the Two German States and Sweden, 1945-1989, ed. Rolf Torstendahl, 79-104. Lund, Sweden: Bloms i Lund Tryckeri AB. 
Walby, Sylvia. 1990. Theorizing Patriarchy. London: Blackwell.

West, Candace, and Don H. Zimmerman. 1987. "Doing Gender." Gender and Society 1 (2): 125-51.

Zimmerman, Klaus. 1993. "Labour Responses to Taxes and Benefits in Germany." In Welfare and Work Incentives: A Northern European Perspective, ed. A. B. Atkinson and Gunnar Viby Mogensen, 192-240. Oxford, U.K.: Clarendon Press. 